\title{
ASSESSING THE STREGTH AND WELDABILITY OF HISTORIC STRUCTURAL STEEL
}

\author{
Jacek DUDKIEWICZ ${ }^{1}$, Bronisław GOSOWSKI ${ }^{2}$, Piotr ORGANEK ${ }^{3}$ \\ Wrocław University of Technology, Faculty of Civil Engineering, Wrocław, Poland
}

\begin{abstract}
In practice, in the design stage of revitalization, renovation or reinforcement, there is often a need to determine the strength of steel as well as its weldability. The strength of steel can be determined in two ways: directly through destructive testing or indirectly by the Brinell hardness test. In the case of weldability, this turns out to be much more difficult, because there are three groups of factors which determine this property, i.e.: local weldability, operative weldability, and overall weldability. This paper presents the results of the verification of the relationship between the hardness and strength of three grades of steel from the early twentieth century. The evaluation of the overall weldability of structural steels is discussed in an analytical approach preceding costly weldability tests. An assessment based on selected indicators of weldability can only lead to confusion.
\end{abstract}

Keywords: strength of steel, Brinell hardness, weldability, weldability indicators, weldability testing, historical steel

\section{INTRODUCTION}

In engineering practice, mainly at the stage of designing the revitalization, remodeling or the reinforcement of a construction, it often turns out that we do not have reliable data on the applied grade of steel due to a lack of design plans for the erected building structures. This pertains practically to all buildings

\footnotetext{
${ }^{1}$ Corresponding author: Wrocław University of Technology, Faculty of Civil Engineering, Wybrzeże Wyspiańskiego 27, 50-370 Wrocław, Poland, e-mail: jacek.dudkiewicz@ pwr.edu.pl, tel. +48713202288

${ }^{2}$ Corresponding author: e-mail: bronislaw.gosowski@pwr.edu.pl, tel.+48713204122

${ }^{3}$ Corresponding author: e-mail: piotr.organek@ @wr.edu.pl, tel.+48713203420
} 
created prior to World War II, as well as modern-day buildings, due to the lack of care taken by investors in safekeeping as-built design documents. What is more, when planning to strengthen a construction by applying welding to connect elements, it is key to assess the weldability of these steels. While the strength of steel can be assessed in two ways: directly, based on destructive studies on a sufficient amount of samples taken from the construction, or indirectly, by the Brinell hardness test, in the case of weldability, this is more difficult. This is seeing as how three groups of factors affect this property: local weldability, overall weldability, and operative weldability.

\section{ASSESSING THE STRENGTH OF STEEL}

\subsection{Indirect method of estimating the strength of steel using Brinell hardness measurements}

The indirect indication of the design strength of steel is usually impossible due to the lack of possibility of taking relatively large pieces of steel sections or sheets to create fivefold samples for carrying out destructive tests [5], while their amount can be no smaller than three in regards to each of the main construction elements.

Much larger possibilities are provided by the indirect method, in which strength parameters are indicated on the basis of Brinell hardness measurements [5]. In contrast to the direct method, assessing the hardness of steel can be carried out on the existing construction in a non-destructive way, which makes it possible to obtain an optional number of measurements, and is advantageous in the case of subjecting them to statistical analyses. The method is recommended for raw or normalized steel, which we usually come across when dealing with steel building constructions. Measurements of the hardness can be carried out in a testing station on small samples of steel taken from the construction or on site, directly on the actual construction elements (in a non-destructive way), using a portable hardness tester (cf. Fig. 1a). In order to improve the effectiveness of reading the diameter of the impression and make it easier to carry out in difficult to access locations, it is recommended that electrical measurement microscopes be used (cf. Fig. 2b), facilitating the registration of the image of the impression on a computer (cf. Fig. 1c), based on which the readings of the diameters of impressions are taken.

In article [9], the methodology of determining the calculation strength parameters of building structure steel was presented for of a limited number of samples, applied in direct as well as indirect studies. 
a)

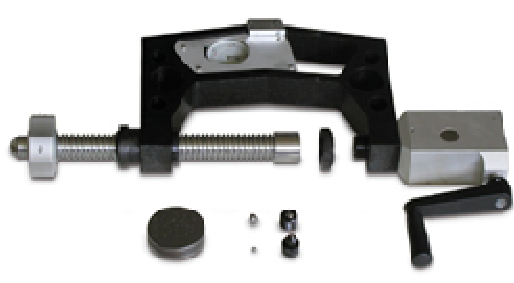

b)

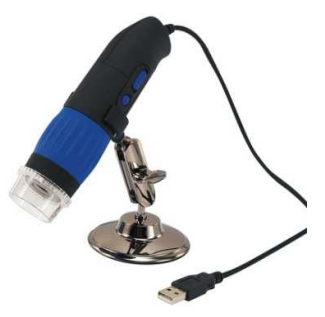

c)

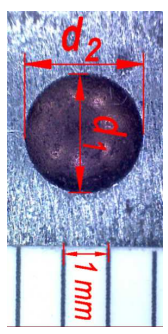

Fig. 1. Portable Brinell hardness tester PZ-3 (a), measuring microscope (b), photograph of impression with scale (c)

\subsection{Verification of the dependency between the hardness and strength of historic steel}

The indirect method of assessing strength is based on a known linear relation between Brinell hardness and strength parameters of steel (1), i.e.: stress yield $R_{e}$ and tensile strength $R_{m}[4 \div 6,8]$.

$$
R_{i}=a_{i} \cdot H B W_{0} \text { for } i=e, m,
$$

where:

$i=e, m$ - respectively: for stress yield and tensile strength,

$a_{i}$ - coefficient dependant on the type and grade of steel,

$H B W_{0}$ - Brinell hardness tested on an unbiased sample

In technical literature, there is a lack of information regarding $a_{i}$ coefficients for past structural steel, which limits the use of the indirect method of estimating its strength parameters.

Currently, there are still many buildings constructed prior to World War II whose main load-bearing structure is made of steel. Often, due to the many-year period of use, they require repairs and reinforcement. Thus, knowledge regarding $a_{i}$ coefficients for historic steel is necessary from the practical point of view, as it would enable the safe application of the indirect method also in the case of historical buildings from the past.

The verification of dependencies (1) was carried out on three sets of steel derived from different periods of time. The first collection (A) comprised 15 flat samples made from the webs of normal type 100 structural channels dating back to the 30's of the past century and taken when strengthening the steel construction of the roof of a historic school in Wałbrzych [7]. The second set (B) consisted of 8 flat samples from the lower strip of a steel truss from a production hall built in the 20 s of the past century [10]. The third set (C) was 
comprised of 4 flat samples made of steel sheets measuring $14 \mathrm{~mm}$ in thickness, taken from the web of a plate girder of a train bridge from the 90's of the XIX century.

Four Brinell hardness measurements were taken on each of the samples using a PZ-3 portable hardness tester (Fig. 1a), in accordance with the European norm PN-EN ISO 6506-1:2008. A total of 124 observations were made (set A: 60, B: 32 and C: 32 observations). The indenter used was a tungsten carbide ball with a diameter of $\mathrm{D}=5 \mathrm{~mm}$, impressed into the surface of the samples with a test force of $\mathrm{F}=7355 \mathrm{~N}$. Then, following hardness measurements, flat samples (fivefold, subjected to machining) underwent a static tensile test (in accordance with PN-EN ISO 6892-1:2010), determining the yield limit and tensile strength of the steel.

Converting the dependencies (1), $a_{i}$ coefficients were calculated for each of the sets. Average values of these coefficients have been compiled in Table 1 next to the appropriate coefficients for various grades of structural steel taken from technical literature.

Table 1. Values of $a_{i}$ dependency coefficients (1) for various grads of steel

\begin{tabular}{|c|c|c|c|c|c|c|c|c|c|c|}
\hline \multirow{2}{*}{ Steel } & \multicolumn{6}{|c|}{ Acc. [4, 6, 8] } & \multicolumn{3}{|c|}{ Own research } \\
\cline { 3 - 11 } & St3SX & St3SY & St3S & $10 \mathrm{HA}$ & $18 \mathrm{G} 2$ & $18 \mathrm{G} 2 \mathrm{~A}$ & A & B & C \\
\hline \multirow{2}{*}{ Coefficients } & $a_{e}$ & 2.19 & 2.30 & 2.33 & 2.23 & 2.40 & 2.39 & 2.42 & 2.45 & 2.54 \\
\cline { 2 - 11 } & $a_{m}$ & 3.14 & 3.29 & 3.28 & 3.16 & 3.45 & 3.11 & 3.22 & 3.14 & 3.57 \\
\hline
\end{tabular}

The values of $a_{i}$ coefficients for historic steels are higher than those indicated for various structural steel grades (St3SX, St3SY, St3S, 10HA, 18G2, 18GA), and increase along with the age of the steel. This may be caused by the aging process of steel which takes place spontaneously (very slowly) with the passing of time, as a result of which the yield limit and tensile strength of steel increases, while elongation decreases. Rimming steel of low carbon content is especially susceptible to the aging process. Because of this, it is necessary to expand the analyses to include the testing of chemical composition.

In the case of $a_{m}$ coefficients of historic steel, its values for sets A and B are similar to those obtained for St3X, St3Y and St3S.The value of the $a_{m}$ coefficient for set $\mathrm{C}$ steel is, on the other hand, significantly higher than the others.

\subsection{Summary}

The indirect method of indicating the calculated yield limit and tensile strength of steel by non-destructive measurements of its Brinell hardness ought to be considered worthy of recommending in the case of the lack of possibility of doing so by means of the direct method [9]. This method is recommended in the 
case of steel applied in building structures, which usually occurs in an as rolled or normalized condition.

Preliminary research on the dependency between the hardness and strength of steel dating back to the end of the XIX and beginning of the XX centuries reveal that the values of $a_{i}$ coefficients from dependencies (1) clearly differ from those known for currently applied structural steel (St3X, St3Y, St3S, $10 \mathrm{HA}, 18 \mathrm{G} 2,18 \mathrm{G} 2 \mathrm{~A})$. This is presumably the effect of the aging of steel, thus the necessity for its chemical analysis and confirmation of whether the analyzed steel is susceptible to aging. The influence of the strain of the analyzed element on the results of hardness measurements carried out on it ought to also be taken into account $[4 \div 6]$.

The assessment of the strength parameters of steel by means of the indirect method requires a few dozen hardness measurements and ought to be mandatorily expanded to include the analysis of chemical composition. When carrying out Brinell hardness measurements in a non-destructive way, one ought

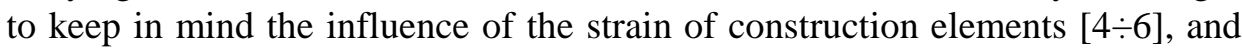
attempt to do so in areas under minimal, optimally zero, strain.

Literature does not contain these types of studies on past structural steels, thus it is expedient to assume research on this topic for a greater amount of historical steel.

\section{ASSESMENT OF STEEL WELDABILITY}

The factors influencing the weldability of steel listed at the beginning are respectively referred to as local, overall, and operative weldability. Weldability can therefore be interpreted as the resultant of the three above-listed factors. The easiest to assess is local weldability. This assessment is carried out based on a system of weldability indicators calculated based on chemical composition. The positive results of this assessment do not confirm steel weldability, but rather justify carrying out weldability tests $[2,5,11]$ in order to determine the remaining constituents of weldability (overall and operative). These are laborintensive and require appropriate research equipment, thus also costly.

\subsection{Preliminary assessment of weldability}

A very useful tool for the initial assessment of weldability (local) is the system of weldability indicators [11]. These indicators, in the form of empirical mathematic dependencies, describe the susceptibility of steel to hot, cold, lamellar and reheat cracking. It does not account for the thermal conditions of welding, thus only the qualitative assessment of susceptibility to cracking is 
possible (on a three-level scale: resistant, partially resistant, susceptible; or twolevel: resistant, susceptible.

A commonly known and readily applied indicator of local weldability is the carbon equivalent $C E V$, which informs us about the intensiveness at which the alloying components influence the creation of friable, hardening structures (martensite, bainite) in the heat-affected zone (HAZ), which are conducive to cold cracking. PN-EN 10025-1 recommends the formula provided by the International Institute of Welding (2) for calculating the equivalent of structural steel carbon (specified in PN-EN 10025-2 $\div 6$ ):

$$
C E V=C+\frac{M n}{6}+\frac{C r+M o+V}{5}+\frac{N i+C u}{15} .
$$

PN-EN $10025-2 \div 6$ provides maximum carbon equivalent values accounting for the thickness of the product.

In the case of steel containing less than $0.16 \%$ carbon, which usually occurs in the case of historic structural steel, the carbon equivalent is better described by the formula developed by Ito and Bessyo [1]:

$$
C_{R}=C+\frac{S i}{30}+\frac{M n+C u+C r}{20}+\frac{N i}{60}+\frac{M o}{15}+\frac{V}{10}+5 B .
$$

In addition to (2) and (3), there are many empirical dependencies allowing for the calculation of indicators for assessing the susceptibility to various types of cracking. These are clearly presented in detail in [11]. Therefore, limiting oneself to only $\mathrm{CEV}$ (or $C_{R}$ ) is insufficient.

In the initial assessment of weldability (local), it is worth drawing attention to the entry in norm ZN-92 1232-206 which provides information regarding the permissible element contents in steel considered to be weldable (cf. Table 2).

Table 2. Permissible contents of elements in weldable steel acc. ZN-92 1232-206

\begin{tabular}{|c|c|c|c|c|c|c|c|}
\hline \multicolumn{8}{|c|}{ Permissible content of elements, \% mass } \\
\hline $\mathrm{C}$ & $\mathrm{C}+\mathrm{Cr}$ & $\mathrm{C}+\mathrm{Mo}$ & $\mathrm{C}+\mathrm{V}$ & $\mathrm{P}+\mathrm{S}$ & $\mathrm{C}+\mathrm{Ni}$ & $\mathrm{Cu}$ & $\mathrm{C}+\mathrm{Cr}+\mathrm{Mo}+\mathrm{V}$ \\
$\leq 0.25$ & $\leq 0.35$ & $\leq 0.50$ & $\leq 0.40$ & $\leq 0.1$ & $\leq 3.0$ & $\leq 0.6$ & $\leq 0.5$ \\
\hline
\end{tabular}

On the other hand, in [3] it was indicated that, in weldable steel, the content of phosphorus and sulfur (of each of these elements) ought to be $<0.05 \%$, manganese $<1.0 \%$, and silicon between the range of $0.03-0.35 \%$.

\subsection{Assessment of the weldability of steel derived from the 30's of the XX century}

In 2007, the "Renoma" Department Store in Wrocław was expanded. The design called for strengthening the steel construction created in 1929 with 
S355J2 steel elements, using shielded metal-arc welding. At this time, the necessity arose to assess the weldability of the steel used in this structure.

Table 3. Chemical composition of steel from DS "Renoma" [12]

\begin{tabular}{|c|c|c|c|c|c|c|c|c|c|c|c|c|c|}
\hline \multicolumn{10}{|c|}{ Content of elements, \% mass } \\
\hline $\mathrm{C}$ & $\mathrm{Mn}$ & $\mathrm{Si}$ & $\mathrm{P}$ & $\mathrm{S}$ & $\mathrm{Cu}$ & $\mathrm{Cr}$ & $\mathrm{Ni}$ & $\mathrm{Mo}$ & $\mathrm{Al}$ & $\mathrm{V}$ & $\mathrm{Nb}$ & $\mathrm{Ti}$ & $\mathrm{N}$ \\
\hline 0.039 & 0.544 & 0.008 & 0.048 & 0.033 & 0.050 & 0.008 & 0.085 & 0.003 & 0.001 & 0.000 & 0.002 & 0.007 & 0.014 \\
\hline
\end{tabular}

The initial assessment of steel weldability turned out to be positive. The analyses of the chemical composition of representative samples (Table 3) showed that the percentage content of alloying elements falls in the ranges specified in ZN-92 1232-206 (cf. Table 1), and the calculated weldability indicators showed that we are dealing with steel that is resistant to the different types of cracking (cf. Table 4).

Table 4. Selected indicators acc. [11], calculated for steel from DS "Renoma"

\begin{tabular}{|c|c|c|c|c|}
\hline Indicator & Application & & Criterion & Assessment \\
\hline \multicolumn{5}{|c|}{ Assessment of susceptibility to hot cracking } \\
\hline$C_{e k w}=0.02$ & Low-carbon steel & \multicolumn{2}{|c|}{$\begin{array}{c}C_{e k w}>0.45 \text { - susceptible } \\
C_{e k w}<0.15-\text { resistant }\end{array}$} & resistant \\
\hline H.C.S. $=2.0$ & Low-carbon steel & \multicolumn{2}{|c|}{ H.C..S. $<4-$ resistant } & resistant \\
\hline \multicolumn{5}{|c|}{ Assessment of susceptibility to cold cracking } \\
\hline & $C<0.2 \%$ & \multirow{2}{*}{\multicolumn{2}{|c|}{ 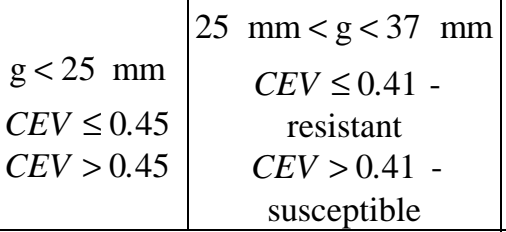 }} & \multirow[b]{2}{*}{ resistant } \\
\hline$C_{R}=0.07^{*)}$ acc. [1] & $C<0.16 \%{ }^{*}$ acc. [1] & & & \\
\hline$T_{p}=-131.6$ & Low-alloy steel & $\begin{array}{r}\mathrm{T}_{\mathrm{p}} \leq \\
20<\mathrm{T}_{\mathrm{p}}<10( \\
\mathrm{T}_{\mathrm{p}}>1\end{array}$ & $\begin{array}{l}20 \text { - resistant } \\
\text { - partially susceptible } \\
00 \text { - susceptible }\end{array}$ & resistant \\
\hline \multicolumn{5}{|c|}{ Assessment of susceptibility to lamellar cracking } \\
\hline$P_{L}=0.35$ & $\begin{array}{c}\text { Low-carbon steel } \\
\text { Low-alloy steel }\end{array}$ & $\begin{array}{r}\mathrm{P}_{\mathrm{L}} \leq \\
\mathrm{P}_{\mathrm{L}}>\end{array}$ & $\begin{array}{l}40 \text { - resistant } \\
0 \text { - susceptible }\end{array}$ & resistant \\
\hline \multicolumn{5}{|c|}{ Assessment of susceptibility to reheat cracking } \\
\hline$\Delta G=-1.98$ & $\begin{array}{l}C \leq 0.18 \% \\
C r<1.5 \%\end{array}$ & $\begin{array}{r}\Delta \mathrm{G} \\
\Delta \mathrm{G} \geq\end{array}$ & $\begin{array}{l}0-\text { resistant } \\
0-\text { susceptible }\end{array}$ & resistant \\
\hline
\end{tabular}

Attention, however, should be drawn to the increased phosphorus and sulfur contents. These elements have a high tendency to segregate and can lead to the occurrence of hot or cold cracks. Some concern is also raised by the high nitrogen content, which indicates that it was not bonded permanently with $\mathrm{N}_{2}$ 
binding elements. This definitely facilitates the aging process, which leads to decreased plastic properties and the increased friability of steel, especially in the area of welding, and possible effects of high temperature derived from, e.g. heat treatment.

Following the preliminary assessment, it was decided to carry out weldability tests for fifteen connections made from cuts taken from the construction of DS "Renoma" as well as sheets of S355J2 steel, manually arc-welded with a coated electrode (smelting with acid rutile-coated electrode, filling with basic-coated electrode) Weldability tests covered a static tensile strength test, bending test with stretching the face and root of the weld, welded-notch toughness test of the weld and heat-affected zones of both of the connected materials, as well a metallographic macroscopic test [12].

In the static tensile test, all welded joints broke apart outside of the weld, in the case of materials from 1929. Similarly, all joints (with the exception of one in which the presence of slag was confirmed), bent to a $180^{\circ}$ angle without cracking on the stretched surface and tearing of the sample edges in the bending test with the stretching of the face and root of the weld. The weld-notch toughness test (at a temperature of $+24^{\circ} \mathrm{C}$ ) showed high Charpy V-notch energy absorption of the weld material (from 108 to $204 \mathrm{~J}$ ), and energy absorption of the HAZ zone of S355J2 steel (from 60 to $208 \mathrm{~J}$ ). On the other hand, the impact energy of SWC steel derived from 1929 is very low (ranging from 9 to $27 \mathrm{~J}$ for as many as 10 of the 15 samples).

Macroscopic studies revealed a characteristic macrostructure of steel from this time period (segregation of the chemical composition and structure, which has been shown in Fig. 2).
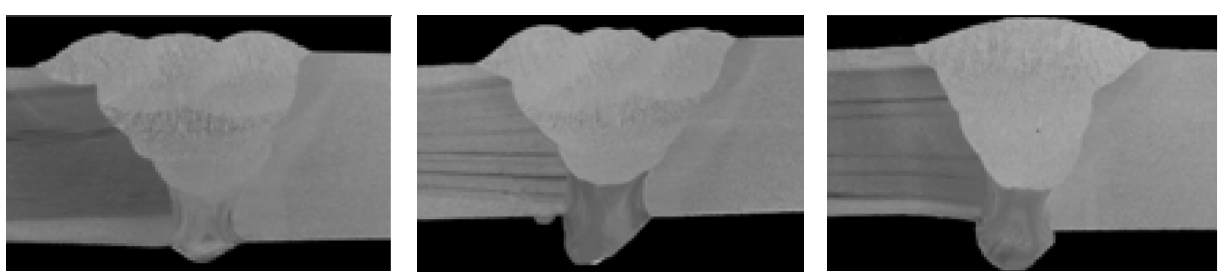

Fig. 2. Macrostructure of the analyzed welded butt joints [12] (on the left, steel from DS "Renoma", on the right S355J2)

Due to the low value of energy absorption of SWC steel, as well as the increased phosphorus and sulfur contents of steel taken from DS "Renoma", it does not fulfill the quality requirements and ought to be treated as nonweldable. 


\subsection{Summary}

The weldability of steel ought to be understood as the resultant of metallurgic, constructional and technological weldability. In order to reach the conclusion that the given steel is weldable, all components of weldability must be positive. If even one of its components is insufficient, steel is considered to be nonweldable.

The assessment of steel weldability begins from the initial assessment of its local weldability, calculating the indicators of weldability on the basis of the chemical composition of steel. If the results of this assessment are positive, the carrying-out of costly constructional and technological weldability tests is warranted. A positive outcome of the tests indicates that steel is weldable, negative - non-weldable. If, on the other hand, the results of the initial assessment of weldability are negative, it is believed that the steel exhibits insufficient weldability.

The proper assessment of weldability is not possible only on the basis of a few selected indicators [11], as they merely provide initial information regarding metallurgic weldability - one of the components of weldability.

\section{REFERENCES}

1. Blicharski M.: Inżynieria materiatowa. Stal. Wydanie II zmienione i rozszerzone, Warszawa, WNT 2012.

2. Butnicki S.: Spawalnosć i kruchość stali, Warszawa, WNTechniczne 1991.

3. Czapliński K.: Dawne wyroby ze stopów żelaza, Wrocław, DWE 2009.

4. Dudkiewicz J., Gosowski B.: Generalizations of relations between strength and hardness of steel in structural elements under longitudinal load, Archives of Civil Engineering, (2004), 50, 1, 45-67.

5. Gosowski B., Kubica E.: Badania laboratoryjne konstrukcji metalowych. Wydanie IV zaktualizowane i rozszerzone, Wrocław, OW PWr 2012.

6. Gosowski B., Dudkiewicz J.: Hardness of longitudinally-loaded steel elements and its relationship to strength, Archives of Civil Engineering, (1997), 43, 1, 23-36.

7. Gosowski B., Gosowski M., Kasprzak T.: Odbudowa po katastrofie sufitu sali gimnastycznej zabytkowej szkoty poddanej termomodernizacji, Wiadomości Konserwatorskie, 26 (2009), 547-557.

8. Gosowski B., Organek P.:Use of the hardness test in-situ for evaluation of strength of steel from the early 20th century. Metal Structures: scientifictechnical conference: short papers, Kielce-Suchedniów, $\pi$ Press Engineering \& Architecture, (2014), 139-142. 
9. Gosowski B., Organek P., Redecki M.: Bezpośrednie i pośrednie wyznaczanie wytrzymatości obliczeniowej stali zastosowanej w konstrukcjach budowlanych, Materiały Budowlane, 3 (2014), 56-59.

10. Gosowski B., Redecki M., Organek P.: Określenie parametrów wytrzymałościowych stali konstrukcji hal firmy Bombardier Polska we Wrocławiu, Raport Serii SPR 15/2014, Wrocław Instytut Budownictwa Politechniki Wrocławskiej 2014.

11. Tasak E., Ziewiec A.: Spawalność materiałów konstrukcyjnych. Tom 1: Spawalność stali, Kraków, Wydawnictwo JAK 2009.

12. Węglowski M., Zeman M.: Badania wtasności ztączy spawanych wykonywach ze stali $18 G 2$ i wyciętych ze starej konstrukcji DH „Renoma” we Wrocławiu, Sprawozdanie nr B-162/07, Gliwice, Instytut Spawalnictwa 2007.

\section{OCENA WYTRZYMAŁOŚCI I SPAWALNOŚCI KONSTRUKCYJNYCH STALI HISTORYCZNYCH}

\section{Streszczenie}

Często w praktyce inżynierskiej na etapie projektu rewitalizacji, remontu lub wzmocnienia konstrukcji pojawia się konieczność wyznaczenia wytrzymałości stali oraz określenia jej spawalności. O ile wytrzymałość stali można określić na dwa sposoby: bezpośredni, poprzez badania niszczące odpowiednio dużej liczby próbek pobranych z konstrukcji lub pośredni - poprzez badania twardości Brinella, to w przypadku spawalności okazuje się to dużo trudniejsze. Bowiem o tej właściwości decydują trzy grupy czynników: metalurgiczne, konstrukcyjne i technologiczne. W referacie przestawiono doświadczenia związane $\mathrm{z}$ zależnością między twardością a wytrzymałością trzech gatunków stali historycznych pochodzących z końca XIX i początku XX wieku. Otrzymane dla nich średnie współczynniki granicy plastyczności oraz wytrzymałości na rozciąganie porównano ze współczynnikami podawanymi w literaturze technicznej dla stali konstrukcyjnych. Omówiono także ocenę spawalności stali konstrukcyjnych w ujęciu analitycznym, poprzedzającą próby spawalności. $\mathrm{Na}$ przykładzie przedstawiono, że ocena spawalności jedynie na podstawie kilku wybranych wskaźnikach spawalności, może prowadzić do pomyłek. Należy pamiętać, że wskaźniki spawalności pozwalają wstępnie ocenić jedynie spawalność metalurgiczną (jedną ze składowych spawalności). Wiarygodny wniosek o dostatecznej spawalności stali można wyciagnnąć wyłącznie po dodatkowym przeprowadzeniu badań spawalności konstrukcyjnej i technologicznej.

Słowa kluczowe: wytrzymałość stali, twardość Brinella, spawalność, system wskaźników spawalności, próby spawalności, stal historyczna 


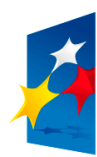

HUMAN CAPITAL

NATIONAL COHESION STRATEGY

EUROPEAN UNION

EUROPEAN SOCIAL FUND

Task is co-financed by the European Union as part of the European Social Fund

Editor received the manuscript: 17.12 .2014 
